\title{
O PODER DO REI NA TRAGÉDIA DE EURÍPIDES
}

\author{
Wilson Alves Ribeiro Jr. ${ }^{*}$
}

Universidade de São Paulo

\begin{abstract}
Resumo. Do ponto de vista histórico, a instituição dos reis gregos é insuficientemente documentada e sua exata natureza está ainda por se revelar. A julgar pela obra dos poetas arcaicos e clássicos, no entanto, as características da realeza ficaram bem gravadas na memória dos gregos do Período Clássico. Nesta oportunidade, foram selecionadas e estudadas algumas passagens da tragédia de Eurípides nas quais a participação do rei pode detalhar ou esclarecer alguns aspectos do poder monárquico nas antigas comunidades gregas e seu reflexo no imaginário dos gregos do século V a.C.
\end{abstract}

Palavras-chave. Realeza; tirania; tragédia grega; Eurípides; história grega.

D.O.I. 10.11606/issn.2358-3150.v18i2p57-73

A PALAVRA "REI", INVARIAVELMENTE UTILIZADA NA LíngUA PORTUGUESA para designar os detentores de poder político pessoal, absoluto e hereditário, reflete melhor as características e atribuições dos reis da Idade Média europeia do que as dos detentores individuais do poder político nas póleis da Grécia Antiga. Usar essa palavra em relação aos gregos da Antiguidade e, mais precisamente, aos do Período Clássico é certamente um anacronismo, mas não há dúvida de que em tempos recuados de sua história as comunidades gregas foram conduzidas por indivíduos com poderes políticos que se assemelhavam aos da realeza europeia medieval.

As primeiras descrições do rei, de seu poder e de seus símbolos podem ser encontradas, como muitos outros elementos da antiga cultura grega, nos poemas homéricos e hesiódicos que refletem, acredita-se, diversos elementos culturais da Idade das Trevas e do alto Período Arcaico. Comparações entre os mitos descritos por Homero e por Hesíodo com os de outras culturas sugerem, ademais, que alguns conceitos remontam à Idade do Bronze do Egeu, talvez até aos precursores indo-europeus da cultura grega. Mitos de várias culturas antigas relatam que os próprios deuses eram sujeitos aos desígnios de um primum inter pares, de um rei dos deu-

\footnotetext{
• Doutor em Letras Clássicas pela Universidade de São Paulo (2011). O arcabouço deste estudo foi apresentado em forma de conferência durante o IV Colóquio do GP Estudos sobre o Teatro Antigo, As relações de poder no teatro greco-romano, São Paulo, FFLCH-USP, 14-16 de agosto de 2012.

**Artigo recebido em 25.set.2015 e aceito para publicação em 14.dez.2015.
} 
ses com poderes absolutos, e Hesíodo realmente conta que, desde a derrota

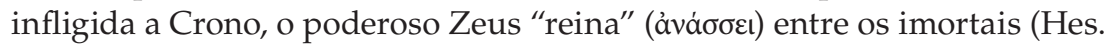

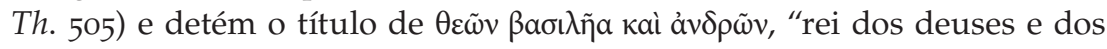
homens" (Hes. Th. 897). Diversos reis humanos míticos eram, por sua vez, considerados seus descendentes, emprestando assim um elemento de divindade ou de sanção divina (Il. 2.204-6) ao poder real. Menciono, apenas para ilustração, Tântalo, rei da Frígia (Od. 11.582-92, Nosti Fr. 3 West, E. El. 4-10), Lacedêmon, rei de Esparta ( $\Sigma^{\mathrm{D}}$ Il. 18.486.65-7), e o herói Perseu, rei de Argos (Ps.-Hes. Fr. 241 = P. Cair. 45624; Pherecyd. 3 F 10).

Nos registros históricos dispomos de poucas informações sobre os tempos mais recuados da cultura grega, todas de natureza arqueológica ou deduzidas a partir dos registros palaciais gravados em Linear B. Na Idade do Bronze havia o wanax, ${ }^{1}$ o lawagetas ${ }^{2}$ e o gwasileus. ${ }^{3} \mathrm{O}$ wanax micênico vivia provavelmente em um palácio como os de Cânia e Pilos e sua influência e/ ou autoridade se estendia a um grande território; o lawagetas parece ter sido um wanax de importância e influência menores, ou pelo menos um de seus colaboradores de status mais elevado, e o gwasileus era aparentemente um simples "chefe" local, talvez um capitão ou comandante militar com atribuições civis, judiciais e administrativas restritas a uma pequena comunidade. ${ }^{4}$

Até o momento, nada leva a crer que esse gwasileus possuía as ca-

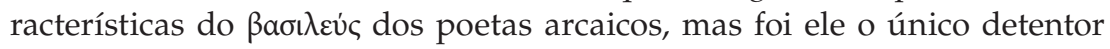
de algum poder pessoal que parece ter sobrevivido ao desaparecimento do sistema palacial micênico no final da Idade do Bronze. Os gregos do Pe-

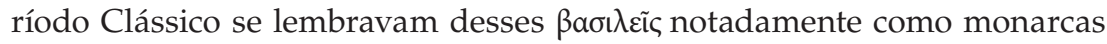
hereditários e em termos bem gerais (Th. 1.13.1 e Arist. Pol. 1284-6b e Ath. 3.1-2). Tucídides (1.13.1), no entanto, afirmou que antes da época das tiranias houve uma época de monarquias ( parece ter sido o primeiro a estabelecer diferenças entre as duas (Mitchel 2013, 2). Aristóteles (1286a-8a), que viveu uma ou duas gerações depois, distinguia várias espécies de governo monárquico e até mesmo considerou "tirânica" um dos tipos de monarquia (1285b).

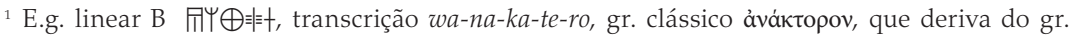
arcaico Fáva

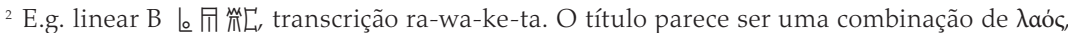

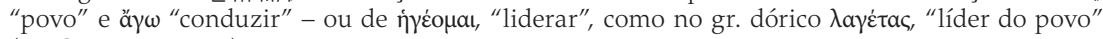
(Pi. O. 1.89; P. 4.107).

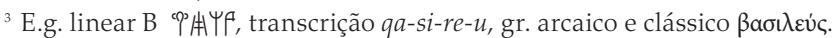

${ }^{4}$ Isso no reino micênico centralizado em Pilos no século XIII a.C., pelo menos.

${ }^{5}$ Note-se que o vocábulo português "monarquia" é praticamente a transcrição latina do vocábulo grego. A primeira ocorrência é um fragmento papiráceo de Alceu (Fr. $6.27=$ = P. Oxy. 1789), nascido em 625-620 a.C. e contemporâneo dos tiranos Melancro, Pítaco e Mirsilo de Mitilene.
} 
Esparta foi a única pólis a emergir da Idade das Trevas com a instituição da realeza hereditária ainda vigente. Os espartanos tinham não

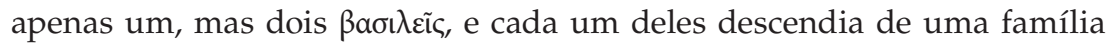
diferente (Agíadas ou Euripôntidas). Durante os Períodos Arcaico e Clássico eles não detinham o poder político e suas atribuições se limitavam a declarar guerra, a comandar o exército, ao direito de participar do conselho "dos velhos" (a gerúsia) e a receber a primeira porção nos banquetes públicos (Arist. Pol. 1285a). Sua autoridade judicial se limitava aos casos de cidadãos que morriam sem descendência masculina e aos relacionados com as estradas públicas e com a adoção de filhos.

Durante o Período Arcaico, oligarcas com poderes discricionários

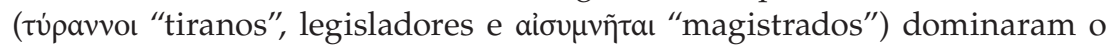
cenário político das póleis gregas (Th. 1.13.1). ${ }^{6}$ Esses homens pertenciam a famílias proeminentes e detinham sozinhos o poder político; eles eram

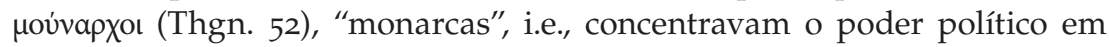
sua pessoa. Ao lado de benefícios à comunidade e de iniciativas e atitudes apropriadas e meritórias, os tiranos arcaicos deixaram más recordações. Heródoto e outros autores antigos lembravam que, além de ostentar acintosamente sua riqueza pessoal e seu poder, eles interferiram politicamente nas póleis vizinhas e se envolveram em guerras de agressão contra elas, interferiram em cultos tradicionais, confiscaram bens, humilharam, exilaram, escravizaram e mataram seus concidadãos, inclusive familiares. A despeito disso, a conotação pejorativa que a palavra "tirano" tem em nossos dias começou apenas no século IV a.C., a partir de Platão.

Embora Tucídides e Aristóteles usem com frequência as palavras "tirano" e "rei" de forma mais ou menos excludente (Parker 2007, 15-7), Heródoto e historiadores tardios as utilizam de forma intercambiável. $\mathrm{O}$

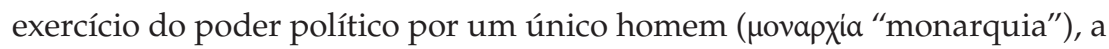
transferência do poder dentro da própria família e as atitudes benéficas e maléficas dos tiranos arcaicos tornaram efetivamente as duas instituições quase indistinguíveis para os gregos do Período Clássico.

Há diversas referências aos monarcas gregos do Período Arcaico nos filósofos pré-socráticos, nos poetas líricos, em Heródoto, em Tucídides, em Platão, em Aristóteles e em historiadores tardios como Diodoro Sículo e Nicolau de Damasco, todos presentes nos modernos tratados sobre a história grega antiga. Uma fonte de informações notável e relativamente negligenciada é, porém, a obra dos poetas trágicos do século V a.C., raramente

${ }^{6}$ A tirania perdurou em algumas póleis até o século II a.C. (Dillon \& Garland 1994, 29), embora os historiadores modernos denominem "Idade dos tiranos" apenas o período que vai do início da tirania de Cípselo em Corinto (c. 658 a.C.) até a queda dos psistrátidas em Atenas (c. 510 a.C.). 
mencionada nesses tratados, talvez pelo caráter eminentemente ficcional das tragédias. Mas reis são personagens ficcionais mais comuns na tragédia grega do que nos poemas arcaicos e sua participação na ação dramática se baseia provavelmente na memória dos gregos sobre o poder absoluto ou quase absoluto dos monarcas - reis ou tiranos - históricos.

A obra de Eurípides se destaca, entre outras coisas, pela proximidade entre os temas trágicos e diversos elementos da cultura ateniense da segunda metade do século v a.C., o que motivou o presente estudo sobre a características da monarquia em sua obra. As referências são numerosas e, por isso, restringi a análise às características mais ilustrativas do poder real / monárquico na tragédia euripidiana, sem me deter na caracterização de reis não helênicos e na cronologia relativa das tragédias. Toda escolha é pessoal, mas confio ter selecionado as passagens mais representativas do monarca trágico nas tragédias de Eurípides. ${ }^{7}$

\section{DENOMINAÇÃO, SÍMBOLOS E SEDE DO PODER REAL}

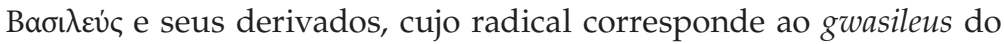
dialeto micênico (e.g. Alc. 241, Med. 455 e 554, Suppl. 444, El. 12, HF 182, Archel. Fr. 229, Hyps. Fr. 752g, Phaëth. Fr. 773 e 781) deveria designar, teoricamente, apenas a figura real de origem hereditária e тúpavvoc ${ }^{8}$ (e.g. Alc. 286 e 1022, Med. 700, Ion 626, Hel. 4 e 35, Ph. 51, Alcmeon em Corinto Fr. ${ }^{*} 76$, Antígone Fr. 171-2, Auge Fr. 275, Tieste Fr. *397b, Dânae Fr. 1132.4), figuras reais de origem não hereditária. Eurípides, no entanto, usava $\beta a \sigma i \lambda \varepsilon v ́ c$ e túpavvoc indiferentemente para designar o monarca, aquele que detinha o poder real. Na Alceste, para se referir a Admeto, ele usa o primeiro termo (241) e, logo depois (286), o segundo.

'Ava乡, palavra que corresponde ao wanax do dialeto micênico, era usada por Eurípides como denominativo ou vocativo genérico para indicar

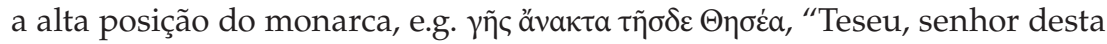

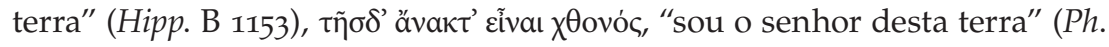

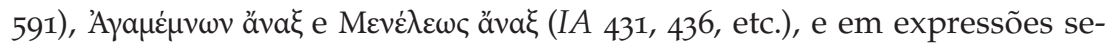

\footnotetext{
${ }^{7}$ As tragédias fragmentárias sem abreviatura padronizada são mencionadas, a seguir, pelo título traduzido.

${ }^{8}$ A palavra não é indo-europeia e sua origem é provavelmente não grega, talvez lídia ou etrusca. Sua primeira ocorrência nos textos gregos é o terceiro verso do Fr. 19 West de Arquíloco:

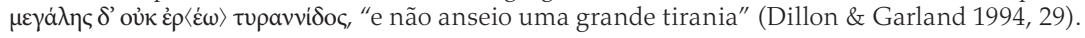


melhantes no Hipólito B (901 e 1249), em Heraclidas (825) e no Alexandre Fr. 56.1. Na Antíope, Hermes recorre a äva para se dirigir a Anfíon, futuro rei de Tebas (Fr. 263.68), e a Lico, o rei que ainda estava no poder (Fr. 223.109).

Essas denominações do rei se estendem à sua consorte e a outros familiares. Alceste, esposa do rei Admeto, é chamada de $\beta a \sigma i \lambda \varepsilon ı$ em Alceste

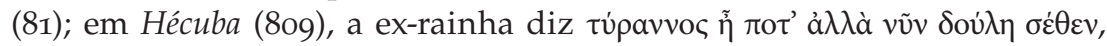
"eu antes era tirana (=rainha) e agora, tua escrava"; em Andrômaca (1055), Hermíone é chamada de "rainha" ( $\beta a \sigma i \lambda \varepsilon \imath \iota)$, e no verso 65 Andrômaca diz que antes de ser escrava era "senhora / rainha" (äva $\sigma \sigma \alpha)$, e o mesmo ocorre com Clitemnestra na Electra (988); no Fr. 822.15 do Frixo A ou do Frixo B, a palavra $\beta a \sigma i \lambda \varepsilon ı \alpha$ é mencionada, possivelmente em relação a Ino. Na Medeia

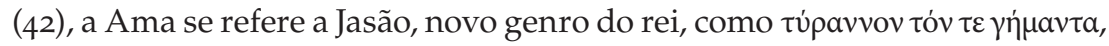
"o tirano que se casou" e, na mesma tragédia (877, 967 e 1356-7), Medeia se refere à filha do rei Creonte como ī túpavvov, "a tirana".

Palavras correspondentes a lawagetas não são encontradas em Eurípides e o nome 'Apxé̉aoc, na tragédia Arquelau (Fr. 228-64), é a única ocorrência do radical $\lambda a o^{-}$em contexto que sugere realeza. Há, porém, algumas ocorrências da palavra $\lambda$ oxajóc, "líder militar de um grupo de homens, capitão" (e.g. Suppl. 598, Tr. 1260, Ph. 123), mas essa função ou posto militar não parece ter tido o alcance que o título micênico lawagetas parece ter nas tabuinhas micênicas.

A sede do poder real é o próprio palácio, residência do monarca

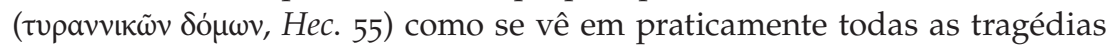
que têm o rei como personagem, e.g. Pelíades (Fr. 601), Fenícias (197), Orestes (1356), Helena (1170), Cresfontes (Fr. 448a2). Note-se que o "palácio" é sede e símbolo do poder político até hoje, haja vista as expressões modernas Paço Municipal, Palácio do Governo, Palácio do Alvorada, etc. Em termos de abrangência geográfica, os domínios do monarca compreendiam a terra dentro dos limites da pólis que ele governava e são quase sempre referidos

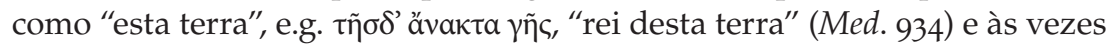
um pouco além (Hipp. B 1084). Há ocorrências semelhantes para túpavvoc em Heraclidas (111), Suplicantes (399) e Dânae (Fr. 1132.4). Na Helena (4 e 1058), a expressão é utilizada em relação ao rei do Egito, cujo comportamento é comparável ao dos monarcas gregos retratados em outras tragédias.

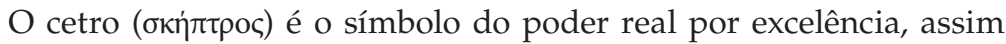
como uma de suas mais frequentes metáforas, e.g. El. 11, HF 213, Tr. 150, Ph. 52, 73 e 80, Or. 437, IA 311 e 412. Passagens corais da Antíope (Fr. 223.17-8)

\footnotetext{
${ }^{9}$ Eurípides escreveu duas tragédias intituladas "Hipólito". Da primeira, abreviatura Hipp. A, temos apenas fragmentos; a segunda (abreviatura Hipp. B) chegou até nós na íntegra.
} 
e da Ifigênia em Táuris (186-7), respectivamente, ilustram com precisão a metáfora:

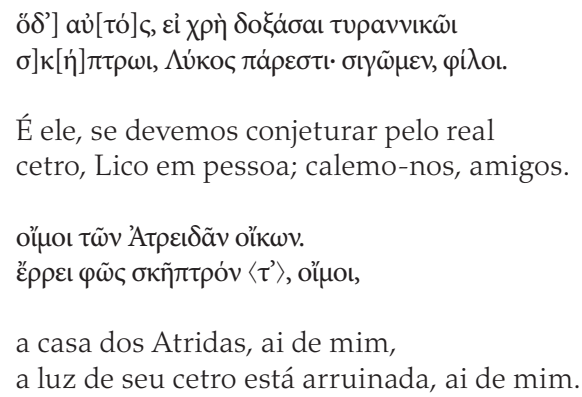

Note-se que na Andrômaca (23, 588 e 1223) o idoso Peleu ainda detinha a dignidade real e usava o cetro, embora Eurípides dê a entender ao longo da tragédia que ele era uma espécie de rei honorário e que seu neto Neoptólemo cuidava de tudo.

Na maioria das vezes, Eurípides usou a palavra $\theta$ póvoc, "trono", para designar simples assentos, mas em alguns lugares a metáfora para a realeza

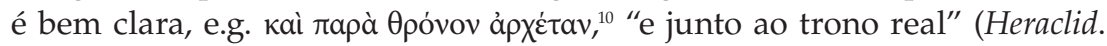

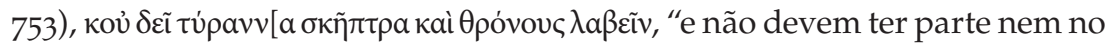

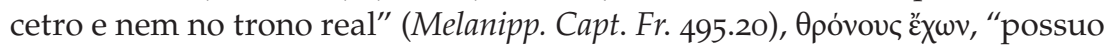
o trono" (HF 167). As rainhas também tinham direito literal de usá-lo, já que Helena, esposa do rei Menelau, sentava-se em um trono dentro do palácio real (Or. 1408-10).

O rei às vezes proclamava pessoalmente suas decisões (Med. 272, 351 e 725; Hipp. B 973-5 e 1084), ${ }_{11}^{11}$ mas dispunha de representante pessoal que atuava à distância, o arauto, para transmitir desejos, decisões (e.g. Heraclid., Suppl. e Hec., passim; Phaëth. Fr. 771-86) e, às vezes, até sua disposição natural. Em Heraclidas, por exemplo, Euristeu é representado por um arauto antipático e agressivo, verdadeiro alter ego do soberano argivo, ${ }^{12}$ mas em Troianas temos o oposto: Agamêmnon é representado por Taltíbio, simpático e compassivo, embora o atrida não fosse sempre assim.

${ }^{10}$ Nessa passagem em particular, Zuntz $(1955,118)$ acredita que se trate de referência ao trono de Zeus.

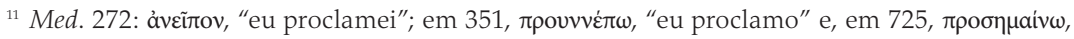

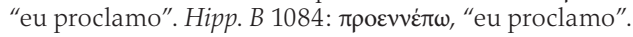

${ }^{12} \mathrm{O}$ rei Euristeu que fala no final de Heraclidas é bem diferente da imagem passada ao longo da tragédia por seu arauto, mas lembremos que nesse momento o exército argivo havia sido vencido e ele, capturado. 


\section{REQUISITOS, IMPORTÂNCIA E VANTAGENS DA REALEZA}

Creusa, filha de rei, naturalmente considerava importante a exis-

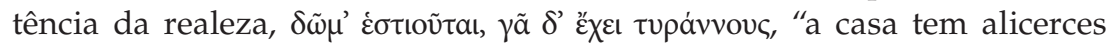
(=filhos), a terra tem reis" (Ion 1464), mas era a pólis que sancionava a realeza, pelo menos segundo o rei Menelau, ao questionar Orestes (Or. 437):

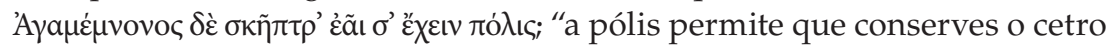
de Agamêmnon?".

Uma das deferências requeridas pelo rei era a preferência de passagem. Em Fenícias (40) Jocasta conta que o cocheiro de Laio exigiu que Édipo desse passagem ao rei (tirano), embora o episódio não tenha acabado bem. A monarquia tinha outros atrativos, tanto que Etéocles, filho de Édipo, preferiu se manter na função de rei em detrimento da segurança de Tebas ( $P h$. 560). Pouco antes (524-5) ele afirmara que, para obter a tirania, valia a pena

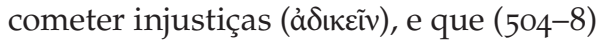

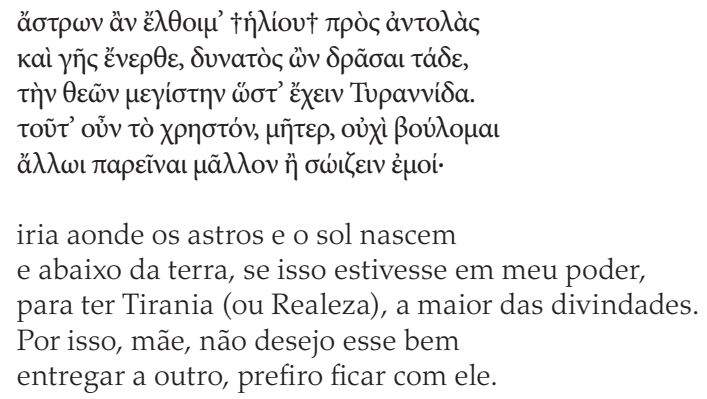

Para Eurípides, a realeza não envolvia apenas poder e prestígio. Jocasta, mãe de Etéocles, revela que o rei aumenta suas riquezas pessoais (552-3 e 566), i.e., já era rico antes da monarquia e depois ficava ainda mais rico. Em Suplicantes (417-22), o arauto de Creonte diz a Teseu que é preciso ter tempo disponível e ser rico para governar a pólis, pois um lavrador pobre precisa trabalhar e não tem tempo para isso.

Não admira, portanto, que o rei combatesse energicamente os que se opunham a seu poder. Ainda em Suplicantes (444-6), diz Teseu:

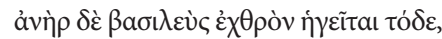

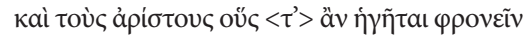

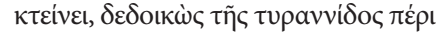

e um homem que é rei os considera um inimigo

e os melhores deles acha prudente

matar, temendo por seu próprio poder. 
A realeza não estava ao alcance de qualquer um, somente membros da aristocracia e seus descendentes podiam almejá-la. No Hipólito B (1283),

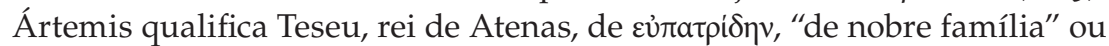
de "nobre nascimento", ${ }_{13}$ e na Alceste (681 e 686-8) o ex-rei Feres diz ao rei Admeto, seu filho:

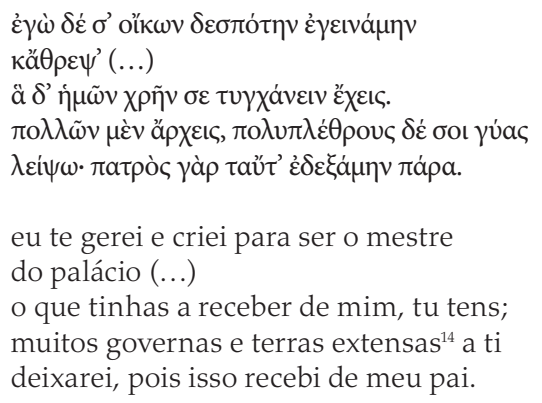

Na Medeia (916-7), Jasão diz aos filhos esperar que, devido ao casa-

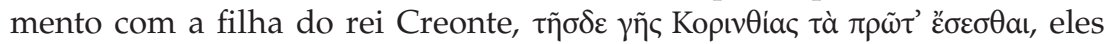
"serão os primeiros desta terra coríntia". Ou seja, a hereditariedade e a propriedade da terra, i.e., a riqueza, eram questões vinculadas diretamente ao poder real e também à sua transmissão.

Outros tipos de vínculo familiar também podiam assegurar a transmissão do poder real. No Íon (57-73 e 808-28), Hermes e o Velho Servidor de Creusa relatam que o aqueu Xuto, pelo casamento com Creusa, reinava em Atenas. Em Fenícias (49-54), Édipo, então um desconhecido que havia derrotado a Esfinge, se tornou rei de Tebas ao casar inadvertidamente com a própria mãe, viúva do rei precedente, morto em circunstâncias mal esclarecidas. O poder podia, portanto, passar pela linhagem feminina, mas não parava nela: era transmitido até o membro masculino mais próximo.

O rei podia, também, entregar voluntariamente o poder. Em Fenícias (71-4), Jocasta conta que seus filhos Etéocles e Polinice haviam combinado, inicialmente, que um cederia o poder ao outro todos os anos, i.e, cada um reinaria por um ano. Na Alceste, depreende-se que Feres passou o poder ao filho Admeto porque assim quis, e o mesmo nos conta Eurípides em Bacantes (43-4), ao descrever a passagem do poder de Cadmo a seu neto Penteu:

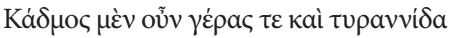

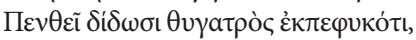

\footnotetext{
${ }^{13}$ Os عủ̇atpíðal, lit. "eupátridas", eram os membros da velha aristocracia ateniense.

${ }^{14}$ Lit. "de muitos pletros".
} 
A honraria e também o poder real Cadmo entrega a Penteu, nascido de sua filha.

Na mesma pólis, posteriormente, Hermes diz a Lico (Antíope Fr. 223.108-9):

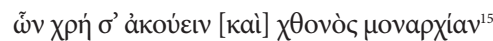

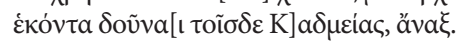

é preciso que a eles obedeças e a soberania sobre a terra de Cadmo entregues voluntariamente, senhor.

Havia, ainda, outras formas de se tornar rei. Eurípides menciona a curiosa disputa pelo trono de Micenas entre Atreu e Tieste na Ifigênia em Táuris $(813-7)$ e no Fr. ${ }^{*} 397$ b do Tieste:

\section{ATPEY $\Sigma$}

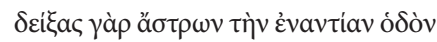

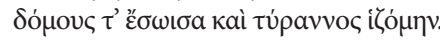

\section{ATREU}

Mostrando dos astros o caminho oposto, ${ }^{16}$ salvei minha casa e estabeleci a tirania.

E quando eventualmente ocorriam problemas de sucessão que não podiam ser resolvidos pelos métodos tradicionais, a sorte decidia: em Heraclidas (34-6), por exemplo, fala-se em $\kappa \lambda \hat{n} \rho \omega \mathrm{l}$, "sorteio". Note-se, porém, que provavelmente se trata de mais um anacronismo, já que esse era procedimento próprio à Atenas democrática do século v a.C.

\section{OS PODERES CIVIS DO REI}

O poder político está concentrado no rei que, em princípio, o exerce sozinho. Em Hipólito B (1015) e em Andrômaca (366), Hipólito e Menelau, respectivamente, se referem ao poder real como $\mu$ ovapxía, "poder de um só". Segundo Etéocles, rei de Tebas, todos são escravos, com exceção do rei:

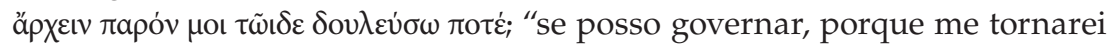
escravo dele?" (Ph. 520). Em Suplicantes (410-3), o arauto de Creonte diz a

${ }^{15}$ Note-se, nessa passagem, o vínculo entre ävał e $\mu$ ovapxiav.

${ }^{16}$ A lenda da mudança de curso do sol, que antes dessa disputa nascia no oeste, é descrita por Apolodoro (Epítome 2.10-14) e por Higino (Fab. 88). 
Teseu que a pólis de onde ele vem (Tebas) é governada por um só homem e não por uma multidão, e nos versos 429-32, o rei ateniense Teseu sintetiza:

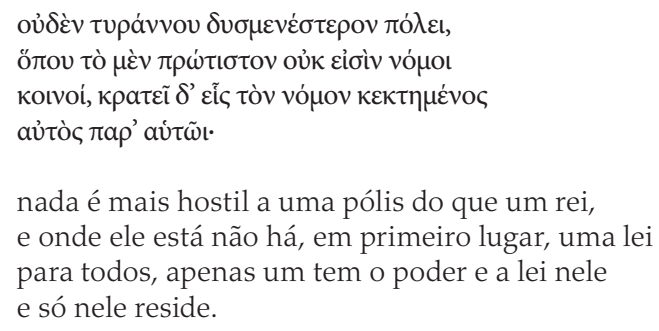

O poder é tão vinculado ao monarca que até o seu nome reflete o po-

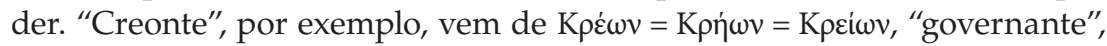
lit. "o mais forte, o mais poderoso". O nome, encontrado em Ésquilo (Sete contra Tebas) e em Sófocles (Édipo Rei, Édipo em Colono, Antígone), também está presente nas tragédias de Eurípides (Medeia, Suplicantes, Fenícias e Alcmeon em Corinto Fr. 75).

A vontade do rei é teoricamente absoluta, real, despótica, "tirânica", envolvendo até vida e morte. No Belerofonte (Fr. 268), o herói afirma que o rei mata muita gente e, efetivamente, em Bacantes (355-7), Penteu ordenou que o "sacerdote de Dioniso" fosse preso e morto por apedrejamento sem ao menos vê-lo, depois de ouvir dizer o que ele aparentemente havia feito. Em Medeia (352-4), Creonte coloca Medeia diante dessa opção, caso fosse desobedecido; em Heraclidas (6o), o arauto de Euristeu diz que Iolau foi incondicionalmente condenado à morte por apedrejamento ${ }^{17} \mathrm{e}$, no v. 964 , coube a Demofonte decidir se o cativo rei de Argos, vencido em batalha, viveria ou não. No Hipólito B (1055-6), Teseu condena seu filho Hipólito sem julgamento e sem nem mesmo ouvir os adivinhos, uma das formas de auscultar a vontade dos deuses. Na Medeia (274-5), Creonte diz a Medeia દ̇ $ү \grave{\omega} \beta$ ßpaßsùs

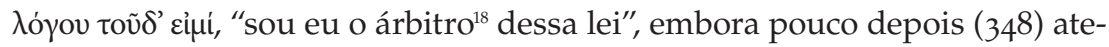
nue a afirmação, dizendo que sua vontade nem sempre é tupavvıkóv, "tirânica". Em Suplicantes (349-50), por outro lado, Teseu diz que a pólis precisa se curvar aos seus desejos, embora coloque tênue verniz democrático nessa despótica atitude:

\footnotetext{
${ }^{17}$ Em outra passagem dessa tragédia (142), o aspecto legal é marcado pela palavra vónoc, que

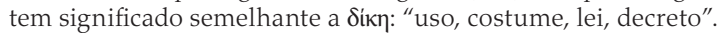

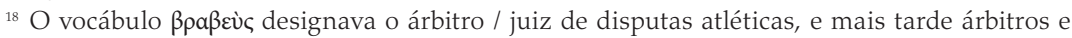
juízes em geral.
} 


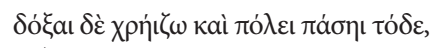

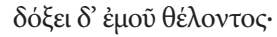

Desejo que a pólis toda ratifique isso

também, pois é o que eu quero.

O cumprimento da vontade real envolvia, algumas vezes, o uso da força. Em Heraclidas (105-6), o arauto de Euristeu diz que poderá usar força contra Iolau e os filhos de Héracles, e antes, nos versos 65-76 e 127-9, já havia tentado arrancar Iolau do altar pela violência; em Fenícias (1660), o Creonte de Tebas ordena que agarrem Antígona e a levem para casa; em

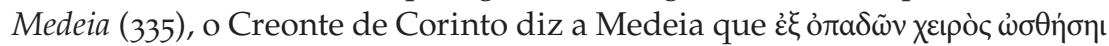
ßiau, "pela mão de meu atendentes serás expulsa à força" e, em Bacantes (43442), um servo conta a Penteu que, conforme ordens dele, caçou e prendeu o forasteiro. No Hipólito $B$ (1084), Teseu ordena aos seus escravos que expulsem Hipólito e, pouco antes (974-5), já dissera que Hipólito não poderia ir

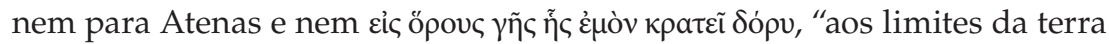
submetida por minha lança".

O rei decidia, portanto, quem podia ou não ficar na pólis, admitindo novos cidadãos ou expulsando quem lá vivia. Em Heraclidas (153-4), Demo-

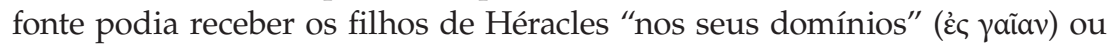
mandá-los embora. No Hipólito B (893-8), o rei Teseu expulsa de Trezena e de Atenas seu filho Hipólito e em Medeia (272-6, 352-4 e 706), Creonte exila Medeia e seus filhos de Corinto, embora nenhum deles fosse, originalmente, cidadão coríntio. Esse poder aparentemente se estendia aos súditos que estavam fora da sua terra, já que em Heraclidas (99-100) Euristeu exigiu a devolução de Iolau e dos filhos de Héracles a Argos. Nos versos 68 e 105, seu arauto explicou que eles pertenciam a Euristeu, eram propriedade dele, mas nos versos 139-43, diante do rei Demofonte, procurou levar a coisa para o lado legal, afirmando que se tratava de fugitivos condenados à morte pela lei de Argos.

$\mathrm{O}$ poder do rei se estendia às posses e, do ponto de vista sexual, às filhas dos cidadãos. Em Suplicantes (450-4), Teseu diz ao arauto de Creonte:

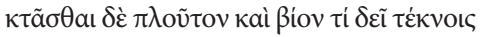

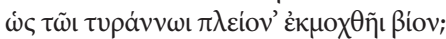

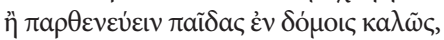

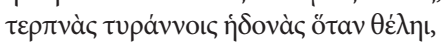

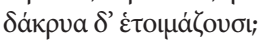

é preciso adquirir riquezas e bens para os filhos 450 e aumentar a riqueza do rei com seus bens?

Para que criar donzelas em casa, virtuosamente, afim de que reis tenham seus prazeres sempre que querem, provocando lágrimas nos que entregam [as donzelas]?
} 
Na prática havia limites ao poder real e alguns atos do rei podiam ser criticados e eventualmente considerados desmedidos. Em Bacantes (671),

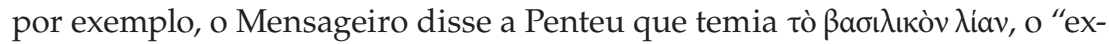
cesso do poder real" e, em Fenícias (1651), Antígone diz a Creonte que o decreto $(\delta i \kappa \eta v)^{19}$ que proibia o enterro de Polinice não seguia o costume (oủk ع̈vvouov). No Fr. 172 da tragédia Antígone, alguém afirma:

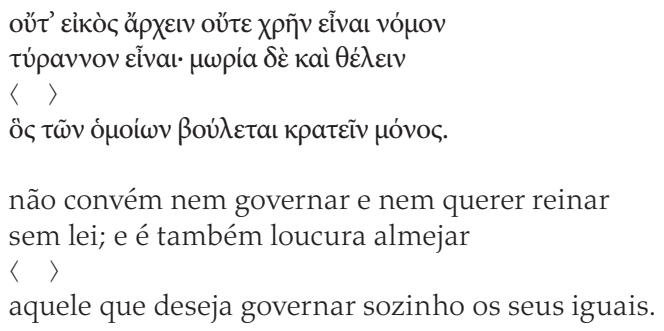

As decisões do rei podiam ser eventualmente criticadas e até revogadas ou moduladas por ele, após súplica ou interferência de parentes. $\mathrm{Na}$ Medeia (349-55), Creonte estendeu um pouco o prazo de permanência da exilada Medeia em Corinto, após súplica formal; nessa mesma tragédia, Jasão tentou fazer o rei revogar o exílio dos seus filhos através da intercessão da sua nova esposa, filha dele, que poderia abrandar o rei (939-44), e ela realmente conseguiu fazê-lo (1002-4). E também era possível reclamar. Em Hipólito B (983-1035), Hipólito tenta se defender perante Teseu depois de condenado ao exílio e, na Alceste (677-8) o ex-Rei Feres alega, durante ácida discussão com o filho e rei Admeto:

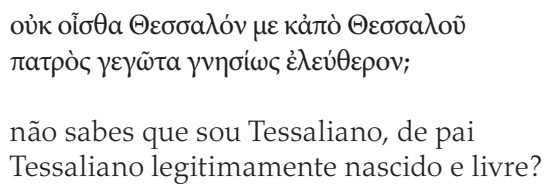

Os nobres que viviam na pólis sem nela ter nascido, no entanto, não tinham liberdade para falar (Ph. 391).

A possibilidade de contestar ou de pelo se queixar das decisões reais implica na existência de uma espécie de código de conduta, provavelmente estabelecido pelo costume, que guiava os atos do rei. Na Antígone (Fr. 171),

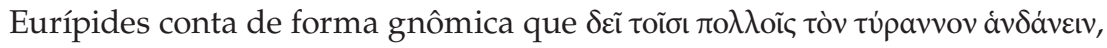
"é preciso que o rei agrade muitas pessoas (=a multidão?)". O rei certa-

\footnotetext{
${ }^{19} \Delta$ ikn: originalmente "costume, uso" e também "pena, sentença"; mais tarde, o resultado de um julgamento ou decisão legal (decreto).
} 
mente não podia ignorar as disposições divinas, como fez Teseu no Hipólito $B$ (1055-6); em Heraclidas (340 e 400-5), antes da batalha entre atenienses e argivos, o rei Demofonte corretamente consultou oráculos e ofereceu sacrifícios para verificar as disposições das divindades e, pouco depois (411-3) afirmou que não podia obrigar um cidadão ateniense a ceder um de seus filhos para ser sacrificado aos deuses, em prol da segurança da pólis.

Em uma das passagens mais interessantes da tragédia Erecteu ( $F r$. 363), o rei ateniense dá conselhos e seu filho e sucessor antes de entrar em batalha, para o caso de perecer. O texto, conservado por Estobeu (3.3), é um pouco confuso devido ao mau estado de conservação, mas é possível distinguir os conselhos de pai dos conselhos de rei. Selecionei os nove dizeres que me parecem mais aplicáveis ao poder real:

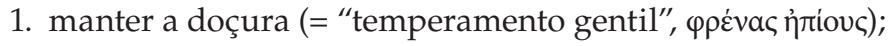

2. para ser respeitado, dar partes iguais, i.e. tratar igualmente ricos e pobres;

3. procurar enriquecer, mas sem adquirir bens por meio de injustiças, a fim de viver longamente no palácio;

4. ter como amigos os que não concordam com tudo, e evitar os que só procuram comprazê-lo;

5. procurar a companhia dos mais velhos;

6. evitar os dissolutos que só procuram prazeres fáceis efêmeros;

7. jamais usar o poder real para satisfazer seus prazeres;

8. não desonrar os filhos de gente pobre e honesta;

9. não permitir que os maus prosperem na pólis.

O rei tinha, portanto, deveres e obrigações. O mais importante deles era ser o mais patriota dos cidadãos e, se necessário, fazer sacrifícios pessoais em prol da pólis. Na Medeia (329), por exemplo, Creonte afirma que a pátria, depois de seus filhos, é o que ele mais aprecia e, em Fenícias (560-1), Jocasta diz que entre ser rei e salvar a pólis, correta é a segunda opção. $\mathrm{O}$

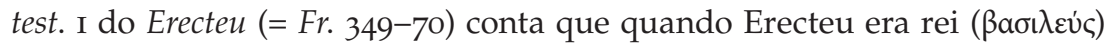
de Atenas, o oráculo de Delfos vaticinou que ele derrotaria os exércitos que ameaçavam a pólis se sacrificasse sua filha, e ele assim o fez. Em Heraclidas, o rei Demofonte esteve diante de um dilema parecido, mas não cogitou sacrificar sua filha ou a de outro cidadão ateniense para defender cidadãos de Argos que, embora acolhidos como suplicantes, não eram atenienses. ${ }^{20}$ No Íon (621-3), Íon pondera:

${ }^{20}$ A filha de Héracles se ofereceu, no entanto, para assegurar a vitória ateniense e a salvação de seus irmãos, resolvendo o impasse trágico. 


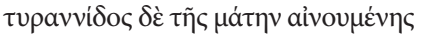

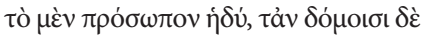
$\lambda v \pi \eta \rho \dot{\alpha} \cdot$

A realeza é exaltada sem razão e, embora a fachada seja agradável, dentro do palácio há tristezas.

O poder monárquico podia, por outro lado, subir à cabeça do rei e ser nefasto aos cidadãos. Mas havia perigo para ambos os lados... No Hipólito $B$ (1013-5), Hipólito diz a Teseu:

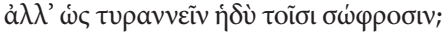

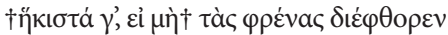

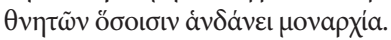
mas ser rei (= tirano) não seria doce para os sábios? de modo algum, se isso destruir a mente dos mortais que se comprazem com o poder único.

E em Pelíades (Fr. 605), diz o rei Pélias a Medeia ${ }^{21}$ :

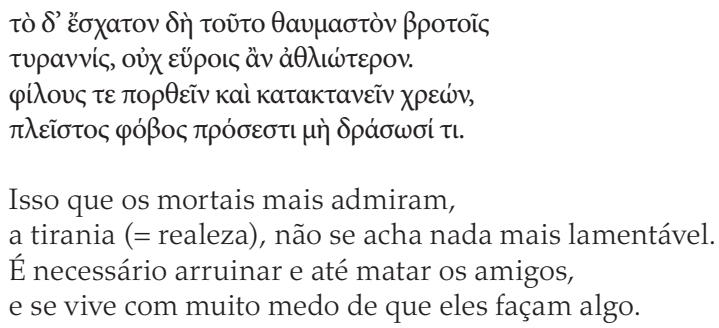

\section{ALGUNS ASPECTOS MILITARES DA REALEZA}

O rei era o comandante do exército da pólis. Em Fenícias, Etéocles lidera as forças tebanas e, embora discuta o assunto com Creonte, cabe a ele decidir a estratégia da batalha. Por falar em estratégia, em Heraclidas 391 há

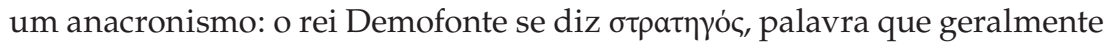
se traduz por "general". Ele comanda as tropas de Atenas e Euristeu, as de Argos. Na Andrômaca (759-60), Peleu ainda controla o exército da Ftia, e na Ifigênia em Áulis o rei Agamêmnon chefia suas forças e todas as outras

\footnotetext{
${ }^{21}$ A atribuição do fragmento a esses personagens é conjetural (Van Looy 2002, 526).
} 
forças gregas que se dirigem a Troia. No Héracles (1163-71), finalmente, o rei Teseu chega a Tebas com um exército ateniense para ajudar Héracles.

Na vida real e também na tragédia, guerras podiam ser tanto agressivas quanto defensivas, como se vê no embate entre Demofonte e Euristeu em Heraclidas. No Beleronte (Fr. 286.5-6), diz o herói:

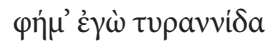

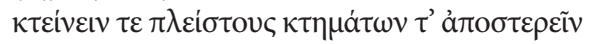

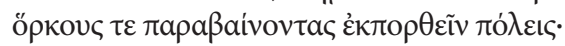

E eu afirmo que a realeza (=tirania) mata muita gente, espolia as posses e viola juramentos saqueando póleis.

Em Suplicantes, Teseu comanda o exército ateniense contra os tebanos, que não querem permitir o enterro de Polinice e dos heróis argivos derrotados. Os soldados, escolhidos entre os cidadãos da pólis (Heraclid. 335), podiam eventualmente desempenhar outras tarefas. Em Bacantes (780-5), por exemplo, Penteu convoca os soldados para combater as bacantes.

Vejamos, finalmente, a curiosa e anacrônica passagem da Ifigênia em Áulis na qual Menelau descreve o comportamento "político" de Agamêmnon para obter o comando do exército grego, formado por contingentes chefiados por outros reis $(337-48)$ :

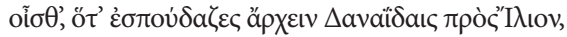

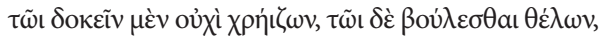

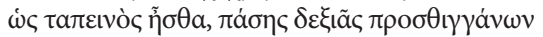

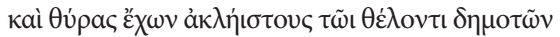

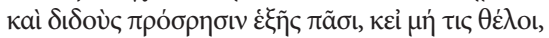

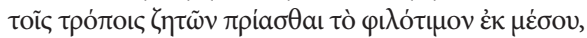

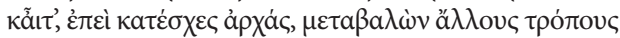

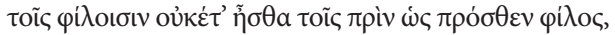

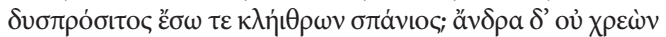

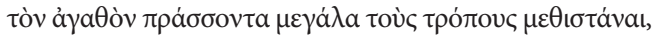

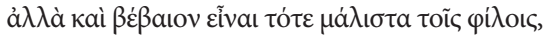

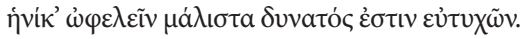

Lembras, quando ansiavas por comandar os Dânaos contra Ílion, sem aparentar que o desejavas, mas querendo muito?

Como eras humilde, de todos a dextra apertando, a porta nunca fechada aos homens do povo que queriam, dirigindo a palavra a todos, um após outro, mesmo aos que não queriam, buscando comprar do público, com esses modos, a honraria.

Aí, quando obtiveste o comando, mudaste para outros modos e não eras, como antes, um amigo para os amigos;

de difícil acesso, raro, atrás de portas. Não deve um homem 
de bem, ao atingir a grandeza, mudar de comportamento, mas ser constante, em especial com os amigos de antigamente; ao prosperar, está apto a lhes prestar grandes serviços.

\section{DOIS REIS?}

Em Eurípides, a existência de dois reis é mencionada de forma incidental e mesmo periférica, e sem relação com a realeza dual de Esparta. Em Heraclidas (34-6), Iolau comenta que Maratona é governada pelos dois filhos de Teseu, mas quando o arauto de Euristeu pergunta quem é o rei, o Coro responde que é Demofonte, filho de Teseu, que se aproxima com seu irmão Acamas (115-9). Em Fenícias (71-6), o arranjo entre Etéocles e Polinice para a alternância anual de poder não funcionou, mas em teoria Tebas tinha dois reis. Seriam os acontecimentos descritos na tragédia um tênue eco de ocorrências antigas ou uma crítica ao sistema espartano?

\section{CONCLUSÃO}

Os benefícios e os malefícios da monarquia, entendida aqui como o exercício do poder político por uma só pessoa, rei ou tirano, eram bem lembrados por Eurípides e pelo seu público. Na memória dos cidadãos do Período Clássico, a somatória dos benefícios e malefícios do poder absoluto era evidentemente negativa, o que Eurípides sintetiza no Fr. 275.1-2 da Auge, atribuído a Héracles (que provavelmente se dirige a Aleu):

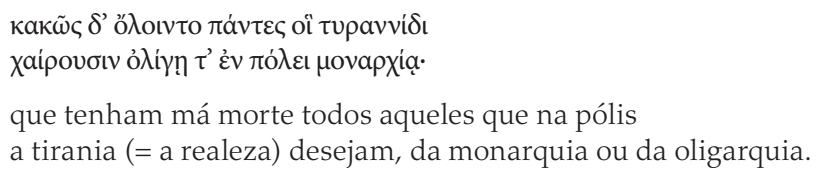

Note-se que nessa passagem o poeta não faz distinção entre o governo de um só e o governo de pequena parte dos cidadãos, aplicável à sua própria época. As passagens analisadas demonstram que os reis das tragédias de Eurípides são muito parecidos com reis e tiranos presentes em poemas épicos e líricos do Período Arcaico e, assim como eles, evocavam antigos personagens e sistemas de governo mal documentados pela história do Período Arcaico, mas que deixaram marcas evidentes na cultura ateniense do século $v$ a.C. 
As tragédias de Eurípides sem dúvida acrescentam detalhes significativos aos nossos conhecimentos sobre a monarquia / tirania arcaica e, se não têm valor histórico formal para os puristas, dada a natureza ficcional do enredo trágico, no mínimo documentam o impacto da monarquia arcaica e suas lembranças na sociedade grega de meados do Período Clássico.

\section{REFERÊNCIAS}

Dillon, M.; Garland, L. 1994. Ancient Greece: social and historical documents from Archaic times to the death of Socrates (c. 800-399 BC). London and New York: Routledge.

Mitchel, L. 2013. The heroic rulers of Archaic and Classical Greece. London and New York: Bloombsbury.

Parker, V. 2007. "Tyrants and lawgivers." In The Cambridge Companion to Archaic Greece, edited by H. A. Shapiro, 13-39. New York: Cambridge University Press.

Van Looy, H. 2002. "ПЕ $\Lambda \mathrm{IA} \triangle \mathrm{E} \Sigma$ : Les Péliades." In Euripide: tragédies, tome 8.2: Fragments de Bellérophon à Protésilas, texte établi et traduit par F. Jouan et $\mathrm{H}$. Van Looy, 515-30. Paris: Les Belles Lettres.

Zuntz, G. 1955. The Political plays of Euripides. Manchester: Manchester University Press.

\section{$*$}

Title. Royal power in Euripides' tragedy

Abstract. On historical perspective the Greek kingship institution is insufficiently documented and its exact nature is yet to be revealed. Judging by archaic and classical poets, however, royal power characteristics were engraved in the memory of Classical Period Greeks. We selected and studied a few verses from Euripides' tragedy were kings presence may detail or clarify some aspects of monarchy in ancient Greek communities and its reflection in the minds of fifth century BC Greeks.

Keywords. Royals; tyranny; Greek tragedy; Euripides; Greek history. 